\title{
Bone Marrow Blasts Decreased by 50 Percent or More Compared to Pretreatment Level
}

National Cancer Institute

\section{Source}

National Cancer Institute. Bone Marrow Blasts Decreased by 50 Percent or More

Compared to Pretreatment Level. NCI Thesaurus. Code C153557.

A semiquantitative finding indicating that the amount of immature mononuclear cells in a subject's sample of nucleated cells from bone marrow has decreased by 50 percent or more over the value recorded for a pretreatment sample from that subject. 